\title{
The use of Corporate Social Responsibility (CSR) as a political tool: A case study of tobacco industry in Swabi, Pakistan
}

\author{
Jamshaid Iqbal*1 $^{* 1}$ Sajjad Hussain $^{2} \mid$ Khalid Khan $^{3}$
}

1. Department of Political Science, University of Peshawar, Peshawar, Pakistan.

2. Department of Political Science, University of Lakki Marwat, Lakki, Pakistan.

3. Department of Finance, Qilu University of Technology, Jinan, Shandong, China.

*Correspondence Email: jamshaid66@gmail.com | jamshaid3@yahoo.com

\begin{abstract}
Corporate Social Responsibility (CSR) is perceived as a major component of contemporary business policies. It is considered as a significant tool for business promotion and survival in the 21st century. The ideas of CSR (Welfare) and the business model, tobacco companies create a contradictory concept as it kills one-half of its chain users. Tobacco companies are strictly prohibited by international and local laws from the promotion of their products. In order to cope up with such strict laws, they start social initiatives. Hence, they take help from the idea of CSR. Through CSR they earned a soft image and entered in politics to influence public policy in their favour. This paper is an effort to discuss the real situation behind CSR initiatives of tobacco industry in Pakistan. Annual reports of Philip Morris Pakistan and Pakistan tobacco Company are analysed. Interviews of local companies' owners or officials, research papers, newspaper articles and related sites have been investigated to get the conclusion. Resultantly, this paper emphasizes on the CSR regulations and centralization. The findings also indicate that tobacco money is directly and indirectly used in politics in the form of CSR.
\end{abstract}

Article History

Received:

June 8, 2020

Last Revised:

May 24, 2021

Accepted:

June 6, 2021

Published:

June 30, 2021

Keywords: Corporate Social Responsibility, CSR, politics of tobacco, tobacco politics, tobacco companies, tobacco industry, tobacco business.

\section{How to Cite:}

Iqbal, J., Hussain, S. \& Khan, K. (2021). The use of Corporate Social Responsibility (CSR) as a political tool: A case study of tobacco industry in Swabi, Pakistan. Liberal Arts and Social Sciences International Journal (LASSIJ), 5(1), 497-509. https://doi.org/10.47264/idea.lassij/5.1.32

Publisher's Note: IDEA PUBLISHERS (IDEA Journals Group) stands neutral with regard to the jurisdictional claims in the published maps and the institutional affiliations.

Copyright: ( 2021 The Author(s), published by IDEA PUBLISHERS (IDEA Journals Group). This is an Open Access article published under the Creative Commons Attribution-NonCommercial 4.0 International License (http://creativecommons.org/licenses/by-nc/4.0/) 


\section{Introduction}

Corporate Social Responsibility (CSR) is defined as continuous commitment in business to act ethically and to contribute economic development of the society. CSR advances the view that corporate organizations should be moral, beneficial and law abiding (World Health Organization, 2003). According to Barnard (1938), CSR analyses moral, social, legal, economic, and physical aspects of environment. Increasing capital of stakeholders is the prime objective of a company. Besides this goal, companies have responsibility to protect the long-term socio-economic and environmental needs of the community (Maslow, 1943). Therefore, many organizations launch social projects to contribute to social spheres. Their CSR activities are being divided into different zones as per their business policies (Rizwan, 2017). On the other side, legal and social sectors prohibit tobacco companies to promote their products openly. However, tobacco companies need marketing to survive their business. Thus, for covering negative sides CSR is used as a shield. It softens the image of their businesses and get public sympathies. This opens an opportunity for the companies to use CSR as a tool for getting personal gains. Apparently, law prohibits tobacco companies from products promotion, but they create ways and means to influences public policy because of their social services. Tobacco industrialists earn a huge amount of money and use it for CSR to build public opinion which influence. Policy makers to mould laws according to their motives. Tobacco usage is responsible for a large proportion of diseases around the world (Simms, 2006). It is a recognized industrial epidemic and health damaging product. It produces a lethal product killing almost half of its consumers. Moreover, smoking, and other uses of tobacco affect many human organs. Smoking causes different type of cancers, coronary illness, pulmonary problems, and numerous other diseases (WHO, 2003).

Therefore, legal provisions are needed to regulate and centralize CSR. It is needed to stop the production of lethal products by using the cover of CSR, which cause millions of deaths. It is also important to stop the use of direct and indirect money (in the form of CSR) in politics. Methodologically, this study was carried out by using qualitative research paradigm. In-depth interviews and focused group discussion were used as tools of data collection from the concerned stakeholders. Primary data was supported by secondary data to analyse the issue taken in consideration in a proper way. This paper is an attempt to focus on the issues of, how the international and local tobacco companies extend their business. How they gain social sympathies through CSR activities. Moreover, it indicates how tobacco money is directly and indirectly (in the form of CSR) used in politics. The broader objective of this paper is to critically evaluate the CSR activities of different tobacco companies in Pakistan. It is to unveil the motives behind the CSR initiatives of the tobacco companies. The specific objectives include: (a) to inquire the use of CSRs for political means in the tobacco industries of Pakistan. (b) to argue for the need of a centralized policy regarding the use of CSRs.

\section{Review of literature}

CSR is characterized as a process promised by an organization to behave in a socially accepted way. CSR programs were created for enterprises to advocate moral, natural wellbeing and work guidelines (Watts, 2000). Tobacco industry-initiated CSR to create their soft image. There is no recognized regulation for CSR, which indicates least principles of social performance. This makes an open door for any organization to introduce itself as a socially responsible organization. In this way, it has encouraged tobacco companies to create CSR and to earn more money through tobacco products sales. According to recent data, tobacco-caused deaths are 
anticipated to ascend 8.3 million people in 2030 (from 5.4 million people in 2005) as there is an increase in tobacco smoking around the world generally and in developing countries especially due to their weak political systems (Tobacco Tactics, 2015). Although tobacco use is widely admitted as the single most important preventable cause of health problems globally. In the developing countries, increase in cigarette smoking is due to the shift of international tobacco companies from the developed world (Al Arabi \& Ball, 1992).

In a study titled: "Economics of Tobacco Taxation and Consumption in Pakistan" it' is argued that Pakistani government has shown no concern towards public health while making tobacco policy. It is only concerned with achieving the revenue target from tobacco and other tobacco related industries. Because of the presence of tobacco industrialists in the parliament no antismoking and taxation policy can be fully carried out (Nayab et al., 2018). Similarly, Tobacco lobby has a powerful presence in the United States legislature since 1990s. It was evident from more than 32 million tobacco related documents that tobacco lobby plays an important role. Phillip Morris rightly said, "we support those who support us". These documents contain the names of lobbyists in different states with the amount they received from tobacco companies. This lobby tries to build a relationship with the companies, try to gain power and influence states legislature. Tobacco companies offer gifts, travel tickets, bar membership, etc. to doctors, officials, and policymakers to build a soft image and to promote their business (Givel \& Glantz, 2001). On the other side, Nayab unveiled the motives behind the CSR. She studied how it is misused by the tobacco companies for making a soft image in Bangladesh in the presence of anti-smoking and anti-promotional laws. Various CSR initiatives like afforestation, health, education, youth anti-smoking initiative, donation to charitable works etc. were used for the purpose to survive in the market and to promote their business (Sunny, 2015).

In the case of European Union (EU), Major tobacco strategies influence public health policy vastly. EU has scrutinized tobacco industry's strategies and concluded that their strategies are designed in such a systematic way to get benefits at any cost. Jobber opine that, tobacco industries are having cordial relationship with policymakers. These companies observe political environment very closely and influence politicians accordingly. European policymakers and companies' officials are famous for having similar economic and political interests. They share information and regarding the industrial regulations and policies to serve their own interests (Hastings \& Angus, 2004). Comparatively Philippines government faces many hurdles when they tried for tobacco control policy. However, all over the world Philippine is now leading in tobacco control policy, as it has implemented "Sin Tax" on tobacco users. They have set an example for other countries especially for the signatory members of federal Convention on Tobacco Control. They also used religious teachings in tobacco control policy to influence more people (Chavez et al., 2014) had stated tobacco industry and smoking in the chronological history of tobacco production and smoking. Recently, it showed declining trend slowly. Though, there are strict laws for all the signatory of FCTC. Tobacco use is very rapidly spreading. Burki et al. (2013), raises a question about the legal status of tobacco use. $\mathrm{He}$ is of the opinion that despite legislation on smoking, millions of people are engaged in smoking. Who will be responsible for smoking harmful effects? Despite warnings on cigarettes packets people are smoking. Is there any gap in the government policy? (Pompel, 2004).

Historically, Tobacco Institute was formed and financed by tobacco industrialists in 1958. It was formed with the objectives to communicate with general public and state for issues tobacco industries are facing. It is founded and financed by tobacco manufacturers association of the USA. Thousands of tobacco industries documents reveal that tobacco marketing i-e, packing, 
product design, and advertising are affected by local and state level regulatory laws. It seeks to undermine those laws and regulations. There are also strong tobacco lobbyists' presence in all states of the USA. As Tobacco Institute document revealed that each cigarettes industry's owner is personally involved in politics (Morley et al., 2000).

On the financial side, the economic worth of engagement in CSR activities is relatively a contentious matter. Companies are under growing pressure to perform certain ethical and social activities due to the advancement in the technology, ease of access to the information, awareness of the effects of tobacco use. Communal pressure is increasing for corporate liability covering all characteristics of corporate operations whether moral, social, legal, or financial by numerous shareholders. Subsequently, companies are responding by issuing CSR associated reports (Rizwan, 2017). In almost every country where there are strict laws and regulation particularly for tobacco. The tobacco industry is engaged in CSR activities to present itself with a positive image among the public. Government needs to consider a ban on tobacco use to reduce the harmful effects of the tobacco and its products (Ahmed, 2015). However, these industries resist the government policy and regulations by sponsoring scientific research, public relation campaign and create ambiguity about smoking hazards. They fund political parties, using front groups, and even hiring lobbyists to protect their interests (Saloojee \& Dagli, 2000).

\section{Framework Convention on Tobacco Control (FCTC)}

Framework Convention on Tobacco Control (FCTC) is the world's first international protocol to make treaty about public health for its member countries. The aim to create this framework convention is to protect public health, social bearings, and economics of tobacco. The FCTC of WHO is an accord that indorses the right of all individuals to the maximum standards of health. FCTC (Article 13) states for the member states to implement and impose full ban on tobacco promotion, marketing, and sponsorship. Due to FCTC in member states tobacco firms are not allowed to promote or market their products. So, they start their activities under the name of corporate social responsibility which offers alternative activities route to achieve the marketing goals and to access more people. Article 5.3 of the FCTC states:

"Activities conducted by tobacco industry are socially responsible to distance its image and reputation from the lethal nature of its product it produces and sells or to interfere in public health policies. Activities that are designated as socially responsible by tobacco industry, directing the promotion of tobacco consumption, is a marketing and public relations strategy that defines the Convention's definition of promotion, advertising, and sponsorship".

According to WHO, the corporate social responsibility of the tobacco industry is an inherent contradiction, because the industry's core functions are against its goals of public health policies with respect to tobacco control (World Health Organization, 2003). WHO issued a paper named "Tobacco industry interference" with tobacco control to support signatory states in executing the guidelines against such interfering of FCTC Article 5.3 The paper states:

"The tobacco companies have misused its financial supremacy, lobbying and marketing machinery, and manipulate the media to disrepute scientific studies and influence member states to market its lethal products. Additionally, the tobacco industry endures to inoculate large charitable helps into social 
programs around the world to produce a soft image in the public under the name of corporate social responsibility" (World Health Organization, 2008).

The tobacco business has utilized its financial force, publicity and marketing tools, and control over media to influence scientific research and governments to deal for the propagation of their harmful items. Moreover, the tobacco business keeps on infusing enormous charitable commitments into social projects societies concerned to make a positive image under the name of corporate social responsibility (Prabhat, 2000). Ellen et al. (2006) enlightened how an organization that produces health-threatening products has used CSR as means of establishing mutually beneficial relationship with stakeholders. As CSR is a burning issue, CSR initiatives have become an important element of corporate communication for tobacco companies (Runhaar \& Lafferty, 2009). Research funded by the US National Cancer Institute (PLOS, 2011) shows that, corporations' probable use corporate social responsibility programs not only for improving its public image but also as a tool of gaining access to politicians, influencing agendas, and shaping public health policies to suit their personal interests.

Recent research by the Tobacco Control Research Group (TCRG) at the University of Bath showed that the tobacco companies use CSR as "an innovative form of corporate political activity" (Gray et al., 2011). They concluded by reviewing the company documents of BAT that one of the key objectives of CSR was helping the company in securing access to the policymakers. Thus, it increases the company's chances of influencing the policy decisions of the government. Taking UK as an example of a case study, the paper shows the ways in which CSR could be used for renewing and maintaining dialogues with policy makers, even in apparently in tolerant political contexts.

\section{Research methodology}

This study is qualitative in nature. The available and most relevant data on the topic is evaluated. Primary and secondary data have been utilized in carrying out this study. Prevailing written work has been carefully studied. The information and data have been accumulated from various research journals, annual reports of multinational tobacco companies, research reports, newspaper articles and related websites. In-depth interviews and focused group discussions with concerned policy makers, growers' associations, cigarette factories workers, farmers, political workers, politicians, and stakeholders of the area supplemented the information.

\section{Profile of major tobacco companies in Pakistan}

As per Pakistan Tobacco Board (PTB) record, there are 20 cigarette manufacturing factories which are functional and taxpayers. Six of these units are owned by the two major payers, i.e. Pakistan Tobacco Company (PTC) and Philip Morris Pakistan formerly Lakson Tobacco Company (LTC). The remaining units are owned by local industrialists. Some of these small units have very low or even zero production in terms of revenue generation. Total number of direct employments in the tax-paying sector comes out to be around 9000 people. Furthermore, around 14 small units also exist in the tax-paying sector; according to Pakistan Tobacco Board (PTB) and central board of revenue's estimates (Khan, 1996). The 20 registered companies in Pakistan listed in both Karachi Stock Exchange (KSE) and Lahore Stock Exchange (LSE). The three registered companies are Pakistan Tobacco Company, Philip Morris Pakistan and Khyber Tobacco Company (LSE, 2010). 


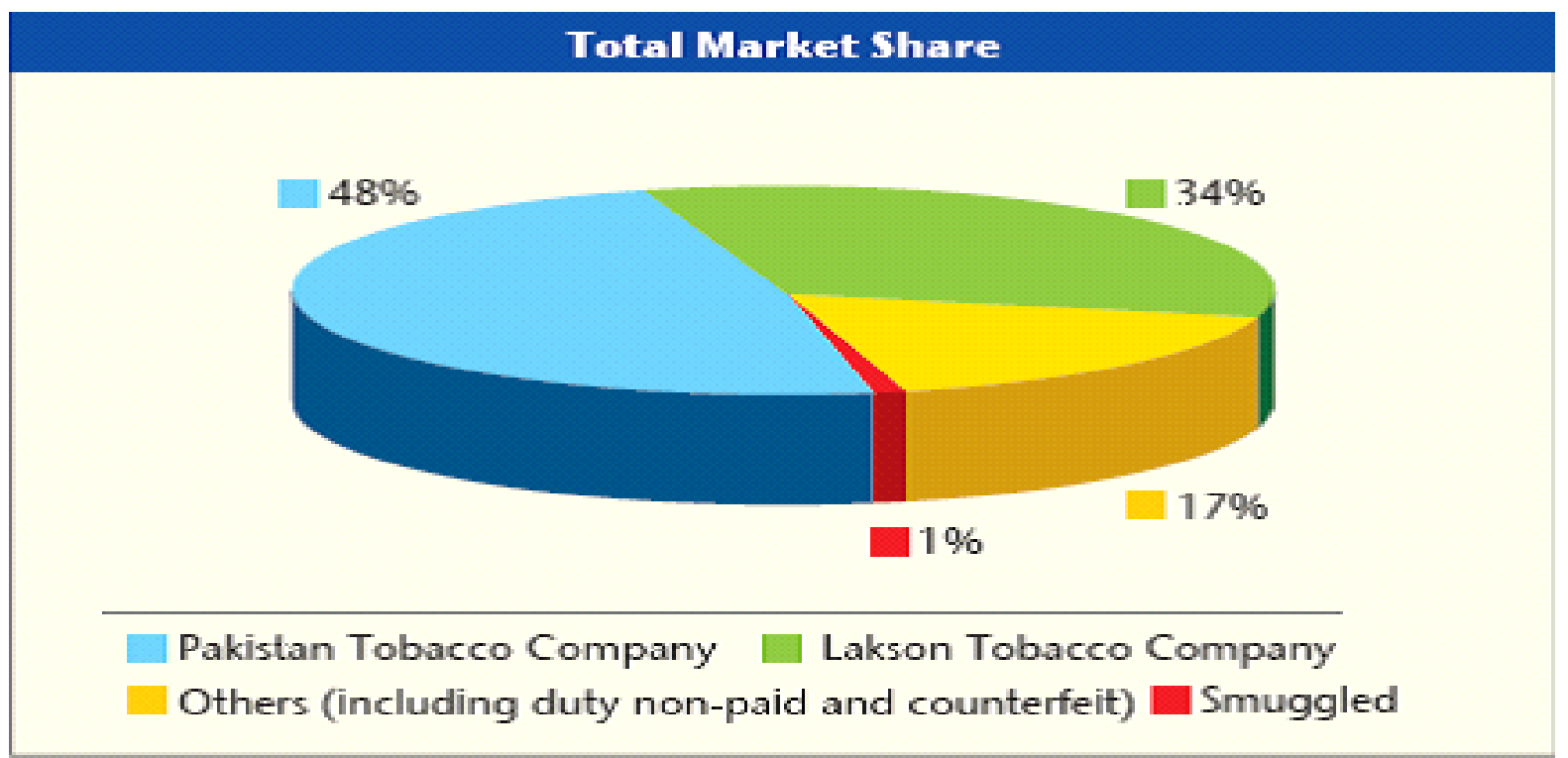

Source: Tobacco statistical bulletin, 2014-15

\subsection{Pakistan Tobacco Company (PTC)}

Pakistan Tobacco Company (PTC) is partner of one of the world's powerful tobacco groups, British American Tobacco (BAT) company reigning over 100 years. The BAT working about in 180 countries around the globe and is acknowledged for its best quality tobacco products (Cox, 2000). BAT company gets functional in Pakistan in 1947. Being the $1^{\text {st }}$ ever multinational organization to start in Pakistan it has endured many difficulties. It proved itself to be the biggest piece of the overall industry holder with 48 percent market shares in Pakistan. In other words, it is simply the market leader in Pakistan. Pakistan Tobacco Company Limited is the one major contributor to Pakistan's National Exchequer. PTC contributed almost over Rs. 86 billion, an expansion of Rs. 12.8 billion, to Government income as income tax, excise duty, sales tax, and custom duties. This has added up to over Rs. 268 million rupees for each working day (PTC, 2020).

\subsection{Philip Morris Pakistan (PMPk)}

In March 2007, Lakson Tobacco Company Limited was purchased over by Philip Morris International which had obtained a greater part in company. The name of the company was changed to Phillip Morris International (PMI) in 2011. Major duty of PMPk is making and offering cigarettes to Pakistan local market. The Company works in 3 cigarette production units with essential and support offices and one tobacco leaf threshing plant in District Swabi, the major tobacco producing area in Pakistan. Other units are situated in different areas of Pakistan. Moreover, it runs a tobacco leaf agronomy program in tobacco developing areas of Khyber Pakhtunkhwa. The company provides unchanging employment to more than 2,500 people. Its enrolment office is in Karachi and its different collecting offices and workplaces are across Pakistan. Philip Morris Pakistan Limited intends to:

- Meet the desires of adult smokers by offering original tobacco results of the quality available in their favoured value classification.

- Produce better yields than its competitors.

- Be a careful corporate national and directing its business with honesty. 
We are committed to the constant improvement of our representatives by giving skilled preparing underlining collaboration, a spotless and safe workplace and administration inculcated with humility. The major brands of the organization are Morven Gold, Red and White, Marlboro, K-2, and Diplomat (PMIPk, 2020)

\subsection{Khyber Tobacco Company (KTC)}

Khyber Tobacco Company is open constrained company and since 1954, it has been working in Pakistan. Khyber Tobacco Company has achieved the status of business with an aspiring vision, extraordinary quality, and alert group with getting a charge out of the status of major few companies in Pakistan tobacco industry. The company extended its operations around the globe in parts of Eastern Europe, West and South Africa, South and Central Asia and Middle East. The mission and vision statement of the organization is as following:

"With universally professed brands, a completely incorporated creation office, and an abundance of experience and aptitude KTC is in a perfect position to give both leaf and mixed tobaccos. Our group of industry specialists plan to present much inquired about brands after thorough testing and mixing of tobaccos from around the globe in order to give the client particularly important experience."

The different brands that are offered by the Company are:

"Gold Street (Premium and International), Classic (Special Flavour, Full Flavour, and Menthol), Hero (International, Lights, and Menthol), Chance No. 1 (Virginia Blend, Special Blend, and Menthol), Virtue (Super Slims and LightSuper Slims)" (KTC, 2020).

\subsection{Other tobacco companies}

There are about 17 other tobacco companies, which are mostly situated in tobacco growing areas, but its contribution to market is nominal. Most of them are engaged in counterfeit business. However, its presence in market makes a competitive tobacco business market and working as pressure group for tobacco business in Pakistan.

\section{Corporate Social Responsibility (CSR) in Pakistan: A discussion}

Various tobacco companies including local and multinational in Pakistan have taken steps to provide health, education, and other social facilities under their CSR programs. It has contributed to being at the forefront of corporate social responsibility through its various initiatives over the past many years.

\subsection{Pakistan Tobacco Company (PTC) and its social commitments}

It has been observed that the initiatives of Pakistan Tobacco Company (PTC) were focused on practical activities and based on participation with its partner societies. It has known areas of support within its scope of operation that could benefit most from its efforts. Some of its contributions are given as follows: 


\subsubsection{Water filtration plants}

Filtration units were operational in Yar Hussain (Swabi), Akora Khattak, Buner, and Isori from the year 2003 onward.

\subsubsection{Mobile Doctor Units (MDUs)}

PTC runs Mobile Doctor Unites (MDUs) in Mansehra, Buner, Yar Hussain (Swabi), Jehlum, Shergarh (Mardan) and AkorhaKhattak (Nowshehra). PTC's big project was cooperation with the National Institute of Health (NIH), the Prime Minister's Program for Hepatitis launched at District Swabi since the year 2003.

\subsubsection{Learning resource centre's}

Pakistan Tobacco Company (PTC) had one Learning Resource Centre (LRC) in the Yar Hussain, District Swabi.

\subsubsection{Education (non-formal)}

This program was introduced in four cities in 2003 through an NGO named Adult Basic Education Society (ABES). PTC financed nine schools at District Swabi and there were 300 students enrolled. Over 80 percent of the students were girls. In 2005, PTC spent around two million rupees on non-formal education.

\subsubsection{Afforestation}

Pakistan Tobacco Company has facilitated plantation of over 43 million saplings in Pakistan till date. Over the last six years, PTC has spent Rs.123 million on CSR initiatives and 92 percent of this amount (Rs. 113 million) was spent in KP (PTC, 2006-07).

\subsection{Lakson Tobacco Company (social work)}

The PMI, (former Lakson Tobacco Company) managed two eye hospitals (completed at a cost of Rs. 62 million) at Swabi and Sahiwal which facilitated 20,000 patients in OPD and performed 1500 surgeries from July 2014 to June 2015. Similarly, free eye camps are regularly conducted to provide treatment for eye-related diseases. A diabetic centre was started in the Mardan district hospital (KP) in 2005 (Hazrat Ali, 2007).

\subsubsection{Afforestation}

Under the flag of afforestation program, PMI started to grow more than two million trees on their own leased land in Jehlum three years ago. These trees are now available to their contracted farmers on reasonable prices which are the costliest input in the process of tobacco production (Irshad, 2018).

\subsection{Imperial Tobacco Industry (social works)}

Imperial Tobacco Industry (ICI) contributed to the CSR through its various projects over many years as follows: 


\subsubsection{Naheed Memorial Welfare Trust (health commitments)}

- In this trust, which was initiated by Imperial Tobacco Industries (ICI), four ambulances are busy in free help of the patients over the years.

- This trust, in coordination with many hospitals, provides free of cost medicine and clinical laboratory facilities to 50-60 patients daily in outdoor patients (OPD).

- Thousands of patients benefited who had Hepatitis ' $C$ ', Cancer and other dangerous diseases. It has sponsored over the years every type of patients in other big hospitals of Peshawar, Mardan and Swabi. ICI contracted to medical stores nearest to the above hospitals on easy process of getting a chit (written approval) from Tarakai House.

- An Eye Trust Hospital provided the latest medical equipment for eye operations [surgeries] and diseases free of cost to every patient.

\subsubsection{Tarakai Welfare Trust (social works)}

- This trust was initiated by Imperial Cigarette Industries. It provided funding for dowry, house building and even day to day commodity to poor people.

- Tarakai Welfare Trust also started a girl's high school in which about five hundred girls are getting free education which is a great facility for the people.

- This Trust bought a two Kanal plot for poor people to use as a graveyard in Kernel Sher killi and one Kanal in Kalu Dher village (near Charbagh, Swabi).

- It established twenty water filtration plants in different union council of District Swabi (SharamTarakai, 2007).

- In the Covid-19 pandemic, the Imperial Tobacco Industry (ICI) and other local industrialists distributed billions of rupees on day-to-day commodities and cash payment in their constituencies.

Tobacco industry and crop had a tremendous impact on economy and politics which is quite clear that through these initiatives people of the area are very loyal to Tarakai House (Owner of ICI). Tarakai House won the District Nazim seat in local elections in 2005 and in general elections of 2008, respectively. For the last fifteen years they continuously dominated the politics of Swabi. This is considered a great political upset in traditional politics (Scholar's observations). Tobacco had great potential which one could imagine from the fact that Lakson Tobacco Company (now PMI) was started in 1971. In a period of less than fifty years, it had become a group of industries which included Colgate Palmolive, Siza pharmaceuticals, McDonald's (the fast-food franchise business), Cyber.net (information services), and Daily Express-an Urdu newspaper, Express Tribune, and Express TV channels. Iqbal Ali Lakani claimed in an interview that my family is paying about three percent of Pakistan total collected revenue (Lakani, 2003). Imperial Tobacco Industries is established in 1990. It has established two other branches in Chakwal and Sargodha. Similarly, it had also bought a five stars hotel in Australia and many big markets at Swabi and other properties in different cities of Pakistan. Apart from Pakistan they also do business in the UK, Canada, and Australia. ICI owners' role in politics is discussed in the coming lines.

\subsection{Other tobacco companies and social works}

In KP other tobacco companies also perform their corporate social responsibilities in a decent manner. Sarhad Tobacco Company sponsors dog bite patients, international Tobacco Company 
provided ambulances and other charitable services to local people. The distinct role of tobacco in revenue-production cannot be ignored. Expenses assumed by growers, workers, and their families had favourable effects on the economy of individual and farming societies. Rich farmers played a vital role in attractive agriculture technologies essential for the progress of other traditional crops. Tobacco revenues lead to health services, supporting schools, water supplies, roads, and environmental development initiatives.

The facilities provided due to tobacco lead to investment formation of further industries including construction, transportation, finance, manufacturing, shops, retail and wholesale businesses, markets and small enterprises that fulfil the requirements of farm labour and their families. All these enterprises would badly affect if tobacco growers' loss the income from tobacco. Therefore, the dispute that food crops should replace tobacco is not suitable. In fact, maximum data indicated that production of tobacco assisted and facilitated the spread of better crop agriculture practices to produce additional crops. Tobacco capability to produce in soils and environments that are not favourable to other food crops also disproves the stance for substituting tobacco with staple crops. In the near future, the tobacco growers are not expected to respond to calls to stop growing of such supportable crops. The growers will continue to invest in the tobacco production. As long as the customers demand exists, tobacco crop will exist. As they are sure that their crop will be sold surely and successfully with a sure reasonable increased price.

\section{Political benefit from CSR by different tobacco companies}

In the 2008 general election, Tarakai House (owner of Imperial Tobacco Industries) gets their position stable through CSR and political background. They did a set back by winning one National Assembly (NA) seat by defeating ANP Chairman Asfandiyar Wali Khan and won one provincial seat independently. The tobacco industry was in need to have representation in the policy-making institution, so in the general election of 2008, these tobacco tycoons had already settled their position. Apparently, they opposed each other and joined different political parties and even one of them with the help of two others made their own political party named Awami Jamhuri Itihad Pakistan (AJIP). They joined PTI and got victory in the history of District Swabi. Total received votes by different political parties in District Swabi in the general election of 2013. For details, see table 1.

Table-1: Election Results of 2008, 2013 and 2018 in NA-19 Swabi II (former NA-12)

\begin{tabular}{|l|l|l|l|l|l|l|l|l|}
\hline \multicolumn{3}{|c|}{ Election of 2008 } & \multicolumn{3}{c|}{ Election of 2013 } & \multicolumn{3}{c|}{ Election of 2018} \\
\hline $\begin{array}{l}\text { Candidate's } \\
\text { Name }\end{array}$ & $\begin{array}{l}\text { Party } \\
\text { Name }\end{array}$ & Votes & $\begin{array}{l}\text { Candidate's } \\
\text { Name }\end{array}$ & $\begin{array}{l}\text { Party } \\
\text { Name }\end{array}$ & Votes & $\begin{array}{l}\text { Candidate's } \\
\text { Name }\end{array}$ & $\begin{array}{l}\text { Party } \\
\text { Name }\end{array}$ & Votes \\
\hline $\begin{array}{l}\text { Usman } \\
\text { Trakai }\end{array}$ & IND & 49872 & $\begin{array}{l}\text { Usman } \\
\text { Tarkai }\end{array}$ & AJIP & 56148 & $\begin{array}{l}\text { Usman } \\
\text { Tarakai }\end{array}$ & PTI & 83903 \\
\hline $\begin{array}{l}\text { Asfand } \\
\text { YarWali } \\
\text { Khan }\end{array}$ & ANP & 49574 & $\begin{array}{l}\text { Haji } \\
\text { Rehmanullah }\end{array}$ & ANP & 35957 & Waris Khan & ANP & 53266 \\
\hline Umer Farooq & PPP & 7100 & Ashfaqullah & JUIF & 21485 & $\begin{array}{l}\text { Maulana } \\
\text { AttaulHaq }\end{array}$ & JUI (F) & 31373 \\
\hline $\begin{array}{l}\text { Said Mukhtar } \\
\text { Ahmed }\end{array}$ & MMA & 1400 & $\begin{array}{l}\text { Anwar } \\
\text { Haqdad }\end{array}$ & PTI & 19557 & $\begin{array}{l}\text { Muhammad } \\
\text { Naeem }\end{array}$ & PPPP & 16158 \\
\hline
\end{tabular}

Source: Election Commission of Pakistan, 2008, 2013, 2018. https://www.politicpk.com/swabi-districtnational-assembly-results-2013-na-12-na-13/ 
Table-2 explains provincial assembly results, most concentrated tobacco production areas in Pakistan and Asia's biggest tobacco market located in NA-19, KP.46-47. On the top position is Awami Jamhoori Itihihad (AJIP) Pakistan. Similarly, in tables 2, 3, 4 and 5 winning positions are the owner of ICI (Tarakai House). They changed traditional politics entirely as they used money extensively in the election cycle. The other industrialists also joined this growing political party, Pakistan Tehreek Insaf (PTI). When PTI came into power in the province, Awami Jamhuri Itihad was merged in PTI in order to get key positions in the party. They got senior health ministry and PTI central committee membership. But in March 2018, on Senate seat, before the general elections of August 2018 breaches generated on the Senate seat between two tobacco tycoons. One joined the ruling party PMLN and the other joined PTI. And thus, one tobacco Tycoon Liaqat Khan Tarakai got succeeded in the Senate seat. He is also the member of Senate Committee for National Health along with others.

At last, these breaches clinched in the shape that they joined setting federal government party as tobacco is a federal subject to get packages for the tobacco industry. They got success not only for themselves but for all tobacco industry. In general elections of 2018, they contested election to set aside ANP as the political environment seemed in favour of ANP before the election. Thus, PTI candidate won the election and was chosen for a local government minister. The other tobacco businessmen are already on key positions in a regional political party ANP. It might be for the next governments to take benefits (Local tobacco industrialist). In the Senate of 2021 Tarakai house got senate seat for second time from ruling party and get succeeded along with another Mardan based young tobacco tycoon. He also became a member of world Parliamentarian Association. Consequently, for the first time in the last fifteen years no tax increase in the national budget for the financial year 2021-22.

Table-3: Elections Results

\begin{tabular}{|c|c|c|c|c|}
\hline Year and Constituency & Position & Candidate Name & Party Name & Votes \\
\hline \multirow{4}{*}{$\begin{array}{l}\text { Election } 2008 \text { result } \\
\text { PK-48 (former KP-33) }\end{array}$} & 1 & Engr. Javid Khan Tarakai & IND & 20700 \\
\hline & 2 & Amir Rehman & ANP & 15600 \\
\hline & 3 & Syed Khalid & $\mathrm{PPP}(\mathrm{S})$ & 987 \\
\hline & 4 & Abid Hussain & PPP & 481 \\
\hline \multirow{4}{*}{$\begin{array}{l}\text { Election } 2013 \text { results, } \\
\text { PK-47 (former KP-32) }\end{array}$} & 1 & Sharam Khan Tarakai & AJIP & 20111 \\
\hline & 2 & Amir Rehman & ANP & 16865 \\
\hline & 3 & Mushtaq Ahmad & JI & 6812 \\
\hline & 4 & Zahoor Ahmad & PTI & 2597 \\
\hline \multirow{4}{*}{$\begin{array}{l}\text { Election results 2013, } \\
\text { PK- } 48 \text { (former KP-33) }\end{array}$} & 1 & Muhammad Ali Tarakai & AJIP & 13247 \\
\hline & 2 & Muhammad Ashfaq Khan & ANP & 10691 \\
\hline & 3 & Zubair Khan & PTI & 5394 \\
\hline & 4 & Arsala Khan & PPPP & 3985 \\
\hline \multirow{4}{*}{$\begin{array}{l}\text { Election results } 2018 \text {, } \\
\text { PK-47 }\end{array}$} & 1 & Shahram Khan Tarakai & PTI & 34851 \\
\hline & 2 & Ameer Rahman & ANP & 21161 \\
\hline & 3 & Ijaz Akram Bacha & PMLN & 19250 \\
\hline & 4 & Muhammad Fayaz & JUI (F) & 355 \\
\hline
\end{tabular}

Source: Election Commission of Pakistan, 2013 and 2018.

\section{Conclusion}

The engagement in the CSR contributes positively to enhancing the extensive sustainability of 
enterprise and society. There is an opinion that higher engagement in CSR initiatives shows the incidence of substantial social capital. Through their CSR programs, tobacco companies have effectively accomplished their objectives to advance the tobacco business as a socially capable industry in Pakistan. The tobacco companies' CSR exercises have imparted their great picture in Pakistani people, as the exercises have suitably fascinated open sympathy. Subsequently, tobacco companies' corporate inspirations are effectively installed in their constructive commitments and in the social estimations of their CSR programs identified with education, network care, health care, and other charity works. It has proved that how tobacco and its related businesses were politicized. What are the motives behind the CSR initiative, which is used for economic and political gains? This study has affirmed that the Pakistani tobacco industries' CSR programs are not part of a certifiable social duty, as indicated by the European Commission and ISO 26000; the socially proficient attempt should undertake responsibilities for the effect of its choices and exercises on society. It has proved that using CSR with different charity names is to protect and increase wealth through gaining power of politics. On the contrary, through their CSR exercises, the Pakistani tobacco companies have accurately disregarded the negative effects of tobacco. Without external help, big CSR projects of the local tobacco companies are beyond the understanding of the common man and society. It is needed to regulate and centralized CSR through legal and constitutional provisions and keep an eye on tobacco industry as it is involved in producing and promoting hazardous products for human health.

\section{References}

Ahmed, N. (2015). The scenario behind the CSR activities of the tobacco companies in Bangladesh: A review on a smoky truth. DU Journal of Marketing, 16(1), 181-191.

Al Arabi \& Ball, K. (1992). Tobacco: A major challenge for the developing world. Tropical Doctor, 22(1), $1-2$. https://pascalfrancis.inist.fr/vibad/index.php?action=getRecordDetail\&idt=5186081

Barnard, C. (1938). The functions of the executive. Harvard University.

Burki, S. J., Pasha, A. G., Pasha, H. A., John, R., Jha, P., Baloch, A., Cherukupalli, R., Chalupka, F. J. (2013). The economics of tobacco and tobacco taxation in Pakistan. https://tobacconomics.org/uploads/misc/2014/05/PakistanReport_May2014.pdf

Chavez, J. J., Drop, J., Lencucha, R., \& McGrady, B. (2014). The political economy of tobacco control in the Philippines: Trade, foreign direct investment and taxation. Quezon City: Action for Economic Reform, American Cancer Society.

Cox, H. (2000). The global cigarette: Origins and evolution of British American Tobacco, 1880-1945. Oxford University.

Ellen, P. S., Webb, D. J., \& Mohr, L. A. (2006). Building corporate associations: Consumer attributions for corporate socially responsible programs. Journal of the Academy of Marketing Science, 34, 147-157. https://doi.org/10.1177/0092070305284976

Givel, M. S., \& Glantz, S. A. (2001). Tobacco lobby political influence on US state legislatures in the 1990s. Tobacco Control, 10(2), 124-134. https://tobaccocontrol.bmj.com/content/10/2/124.short

Hastings, G. \& Angus, K. (2004). The influence of the tobacco industry on European Tobaccocontrol policy. Tobacco or health in the European Union past, present and future. Luxembourg: The ASPECT Consortium, European Commission Directorate-General for Health and Consumer Protection, 195-215. 
http://citeseerx.ist.psu.edu/viewdoc/download?doi=10.1.1.586.4725\&rep=rep1\&typ e=pdf

Jha, P., \& Chaloupka, F. J. (2000). Tobacco control in developing countries. Oxford University.

Khan, M.A. (1996). Pakistan Tobacco Board (PTB) and its contribution towards tobacco crop. Pakistan Tobacco, 20(1-2).

Maslow, A. (1943). Theory of human nature. Psychological Review, 50(4), 370-396. https://psycnet.apa.org/doi/10.1037/h0054346

Ministry of Commerce. (2016). Tobacco statistical bulletin (2016-17). Pakistan Tobacco Board (PTB).

Morley, C. P., Cummings, K. M., Hyland, A., Giovino, G. A., \& Horan, J. K. (2002). Tobacco institute lobbying at the state and local levels of government in the 1990s. Tobacco Control, 11(1), https://tobaccocontrol.bmj.com/content/11/suppl_1/i102.short

102-109.

Nayab, D. M. Nasir, M., Memon, J. A., Khalid, M and Hussain, A. (2018). The Economics of Tobacco and Consumption in Pakistan. Pakistan Institute of Development Economics, Islamabad (PIDE), Islamabad. https://www.pide.org.pk/Research/Economics-ofTobacco.pdf

Philip Morris Pakistan. (2020, June 6). www.philipmorrispakistan.com.pk/

Rizwan, M. S. (2017). Empirical investigations on the wealth protection function of Corporate Social Responsibility (CSR). Doctoral dissertation, National University of Sciences and Technology (NUST), Pakistan.

Runhaar, H., \& Lafferty, H. (2009). Governing corporate social responsibility: An assessment of the contribution of the UN Global Compact to CSR strategies in the telecommunications industry. Journal of Business Ethics, 84(4), 479-495. https://link.springer.com/article/10.1007/s10551-008-9720-5

Saloojee, Y., \& Dagli, E. (2000). Tobacco industry tactics for resisting public policy on health. Bulletin of the World Health Organization, 78, 902-910. https://www.scielosp.org/article/bwho/2000.v78n7/902-910/

Simms, J. (2006). The political economy of the tobacco industry. Appalachian State University. http://citeseerx.ist.psu.edu/viewdoc/download?doi=10.1.1.513.5670\&rep=rep1\&typ e=pdf

Sunny, T.A. (2015). A report on CSR activities of British American Tobacco Bangladesh, United International University, Dhaka.

Watts, P. (2000). Corporate Social Responsibility: Making good business sense. World Business Council for Sustainable Development.

\section{List of interviewees}

Anonymous (Labour in ICI), March 10, 2008 and March 28, 2017.

Hazrat Ali (leaf manager LTC), Swabi: Yar Hussain branch, March 28, 2017.

Iqbal Ali Lakhani, Chairman LTC in Daily Business Recorder, September 12, 2015

Irshad Khan, Leaf Manager Lakson Tobacco Company, Yar Hussain, February 15, 2008.

Irshad Khan, general manager PMI company Mardan, before noon, February 15, 2018.

Jan Bahadur (ex-MPA) and owner of International Tobacco company. June 12, 2017.

Jehan Iqbal (tobacco dealer), May 30, 2020, afternoon.

Shahram Khan Tarakai (district Swabi Nazim and director Imperial group of industries), August 30, 2008. 